\title{
Universal Basic Services: A theoretical and moral framework
}

\author{
lan Gough
}

Forthcoming in Political Quarterly.

\section{Introduction}

The extended crisis of what we can still call the welfare state has provoked proposals for radical, encompassing reform. The gap between the rich and poor is widening, children go to school hungry and dirty, and life expectancy rates are beginning to fall. More people are in work, but work doesn't pay and the so-called 'social security' system provides nothing of the sort. Since the financial crash alternatives have increasingly encompassed economic restructuring. Following growing awareness of the climate crisis some also include radical environmental reform. Let us summarise the present predicament as fragmented and degraded welfare plus financialised, short termist and unsustainable capitalism.

Universal Basic Income (UBI) is perhaps the most all-embracing radical alternative. UBI has become increasingly popular on left, right and centre as a unitary solution to the social and economic fractures and failures in modern society. According to the Compass group 'There is no single silver bullet policy to create a Good Society - but basic income is the closest there is'. But it has also attracted growing criticism, both normative and pragmatic. ${ }^{1}$ I share many of the critiques but I do not rehearse them here. Instead I develop the case for an alternative - Universal Basic Services (UBS).

The idea of UBS was originally developed by the Institute for Global Prosperity in $2017 .^{2}$ It proposed a wider range of free public services that enable every citizen to live a larger life by ensuring access to certain levels of security, opportunity and participation. Here, services mean collectively generated activities that serve the public interest, basic means essential and sufficient rather than minimal, enabling people to flourish and participate in society, and universal means that everyone is entitled to services that meet their needs, regardless of ability to pay. The existing National Health Service (NHS) and public education are obvious examples. The original proposal for UBS advocated an extension of this model of provision to - at least - Shelter, Nutrition, Transport and Information.

Yet money is fungible so government money transfers including UBI permit people to spend income on whatever they want. Public services are not fungible but deliver specific activities or provisions. UBS is less in tune with market ideology than UBI. Unless a robust justification is spelt out the case for UBS will be continually undermined by appeals to respect consumer sovereignty and market democracy. The purpose of this paper is to ground the case for UBS in a broader conceptual and moral framework. 
The argument is in three parts. The first sets out a theory of the common human needs we all share and the satisfaction of which is necessary for a flourishing life. The second develops the idea of the 'foundational economy' as a provisioning system for meeting these needs. The final part restates the case for social rights or entitlements to the satisfaction of basic needs and for collective responsibilities to meet them. It makes the case for public provision across four goals: equality, efficiency, solidarity and sustainability.

\section{Shared needs}

The essence of the argument is to counterpose common human needs to the single-minded pursuit of individual wants. Economic theory gives ontological and epistemic preference to the wants individuals happen to have, whether these are assumed to derive from an individual's innate preferences or their cultural and economic environment. To gain a strong purchase on UBS we must turn to two other schools of thought - Capability theory and Need theory.

The capability approach, first elaborated by Amartya Sen, conceives human wellbeing in terms of the range of substantive freedoms and opportunities that people possess. These 'capabilities' in turn rest on the 'functionings' of people; 'an achievement of a person: what she or he manages to do or to be'. Capability is therefore the set of functionings that a person can achieve - their freedom to lead one type of life or another. Unlike Sen, Martha Nussbaum's capabilities approach goes on to list ten 'human functional capabilities' and is content to identify these in a cross-cultural way: life; bodily health; bodily integrity; senses, imagination and thought; emotions; practical reason; affiliation; other species; play; and control over one's environment. Within these she identifies three 'core' capabilities - of affiliation, bodily integrity and practical reason. But to justify this prioritisation in her later book Frontiers of Justice, she relies heavily on the language of need. ${ }^{3}$

Human need theory has been advanced from a variety of perspectives. In a book with Len Doyal $^{4} \mathrm{I}$ argue that all individuals, everywhere in the world, at all times present and future, have basic needs for participation, health and autonomy. These must be met in order for people to avoid harm, to participate in society and to reflect critically upon the conditions in which they find themselves. The universality of need rests upon the belief that if needs are not satisfied then serious harm of some objective kind will result. This is not the same as subjective feelings like anxiety or unhappiness. It refers to functions not feelings. Basic needs are then the universal preconditions for effective participation in any form of social life. Similarly, Sarah Clark Miller ${ }^{5}$ develops a notion of objective, inescapable, inevitable, urgent, and universal needs, which if unmet will result in the harm of compromised agency.

In turn these basic needs always require certain 'intermediate needs' that are again universal. A list of these would include material factors - water, nutrition, shelter, education and healthcare; non-material factors - security in childhood, significant primary relationships, physical and economic security; and embracing the two, a safe environment. The internationally-agreed 2015 Sustainable Development Goals provide another approach to shared needs - a 'crowd-sourced' method to determine universal global foundations for a just and sustainable economy.

Alongside universality, human needs have two other characteristics. First, they are plural and non-substitutable: they cannot be added up and summarized in a single unit of account. One domain of need-satisfaction cannot be traded off against another. More education is of no immediate help to someone who is ill through malnutrition. Thus certain packages of 
need satisfiers are necessary for the avoidance of harm. This is quite different from consumer preferences in economic theory where substitutability is the default assumption: given a bundle of two goods it is always possible-by reducing the amount of one fractionally and increasing the amount of the other fractionally-to define a second bundle between which a consumer is 'indifferent'. Our alternative has direct relevance to the case for UBS. Meeting different needs and fostering different capabilities requires a set of distinct activities and services, not simply the balm of more money.

Second, needs are satiable. It is highly likely that the amount of intermediate needs required to achieve a given level of participation, health and autonomy diminishes as their quantity increases, eventually plateauing. Thus the contribution of calories, dwelling space, even levels of childhood security, to basic needs can be satiated. The distributive principle entailed by human need theory is sufficiency: to bring all individuals up to such a threshold (though this can be defined in different ways).

But while basic needs are universalisable, need satisfiers - the goods, services, activities and relationships required to meet needs in any given social setting - almost always vary across different historical, geographical and social contexts. This leads to a philosophical and methodological dilemma: how in a democracy can these satisfiers be collectively identified? Need and capability approaches challenge the logical and moral priority accorded to peoples' wants/ preferences in orthodox welfare economics. They counterpose a collective alternative to individual consumer preferences. Yet at the same time, there is a danger of officials, experts or politicians determining for people what they need.

In brief, identifying need satisfiers requires a 'dual strategy': citizen involvement and decentralised practices of various kinds, informed by relevant scientific findings and professional expertise. Applying this perspective, we can envisage in general terms a threestage process: define generic need satisfiers utilising an externally verifiable stock of codified knowledge for example, knowledge about nutrition, epidemiology, or planetary boundaries; complement this by drawing on the experientially grounded understanding that people have in their everyday lives in specific contexts; and confront and attempt to resolve inevitable disagreements that result in forums as open, as democratic, and as free of vested interests as possible. Humans do arbitrate highly complex decision- making in large groups, as evidenced in Elinor Ostrom's research on the communal management of common resources and the observation of large scale societies across the world today. In sum, what is required is a form of procedural rationality. Determining need satisfiers entails a problem-solving process rather than a preference-aggregating one. ${ }^{6}$

\section{Provisioning systems}

Goods and services to satisfy needs must be produced, distributed and utilised. The production, allocation and distribution of many need satisfiers has migrated from intimate to public spheres, of which the production of commodities within markets is the dominant form. This paper recognises the critical role that will continue to be played by private markets, but disputes the dominant economic discourse that imputes exclusive virtue to market provision while denigrating collective provision.

We take issue with the idea of the economy as a uniform space within which nameless and substitutable commodities are produced, exchanged and consumed. The idea of nonsubstitutable need satisfiers entails a different conception of the economy as a network of 'systems of provision'. ${ }^{7}$ The links between production and consumption are structured in 
distinct ways for different groups of commodities. Thus there is the food system, the energy system, the housing system, the education system, the care system, the transport system, and so on. Each provisioning system comprises physical elements (infrastructure, technology, land use, supply chains) and social elements (social institutions such as markets and states, social relationships, and social norms and cultures). But each displays a different structure and dynamic.

This understanding of the modern economy has been extended and deepened in the idea of the 'foundational economy' developed by the 'Manchester School' over the last decade. ${ }^{8}$ The material foundational economy directly delivers a range of essential need satisfiers in contemporary market economies. The main components are: pipe and cable utilities (piped water, waste water and sewerage, electricity supply, domestic piped gas and telecommunications - both copper wire and mobile); transport infrastructure comprising railways, roads, filling stations, car retailing and servicing and all public/social vehicles such as trains and buses; food production, processing and the distribution network including supermarkets; and retail banking services and payments systems. Alongside these is the providential foundational economy, essentially the entire welfare state: health care, education, social care, police and emergency services and public administration. Housing is a critical sector that sits across both domains. The entire foundational economy including the welfare state accounts for about $50 \%$ of both employment and expenditure in the UK and across Europe.

These services are all 'mundane'. They are taken for granted until they fail. 'Between 7am and 9am every workday morning in Europe most citizens use goods and services that draw on economic and social systems which are the everyday infrastructure of civilised life' ${ }^{8}$ They differ from other sectors of the economy in several ways: benefits are delivered through infrastructure, networks and branches, as opposed to the purchase of individual commodities; these sectors are relatively sheltered from international competition; and they provide collective, shared services and other activities in the public interest, for mutual benefit.

There is clearly a parallel between the frameworks of human needs and provisioning systems. Both recognise the irreducible heterogeneity of consumption, the multi-faceted nature of human needs and the variety of systems on which we all depend. Both recognise the importance of shared systems and mutual benefits. Potentially they can both justify the idea of local economies under more local control. 'The historical development of the foundational economy is ... a kind of practical working out of the theory of human needs and capabilities, because foundational provision amounts to a kind of immanent (implicit) moral theory of citizenship'. ${ }^{8}$ Together they provide the conceptual foundations for UBS.

Table 1 provides a provisional map of the links between universal basic needs, contemporary clusters of need satisfiers, and modern provisioning systems. The second column provides a provisional list of contemporary need satisfiers. It is clear that these basic provisioning systems are presently distributed across both the private and public sectors in a shifting pattern. This raises the question, what is the justification for, and the appropriate realm of, the public sector? Can and should free universal provision be extended through the public realm? 
Table 1. Linking needs and provisioning systems: The potential components of UBS

\begin{tabular}{|l|l|l|}
\hline Universal needs & $\begin{array}{l}\text { Contemporary need } \\
\text { satisfiers }\end{array}$ & Provisioning systems \\
\hline \multirow{2}{*}{ Nutrition } & $\begin{array}{l}\text { Adequate nutritious diets; } \\
\text { food security }\end{array}$ & $\begin{array}{l}\text { Agriculture, food processing and } \\
\text { food retailing systems: 'from field to } \\
\text { fork' }\end{array}$ \\
\hline \multirow{5}{*}{ Shelter } & $\begin{array}{l}\text { Adequate, secure, } \\
\text { affordable housing }\end{array}$ & $\begin{array}{l}\text { Housing: land, building, owning, } \\
\text { letting }\end{array}$ \\
\cline { 2 - 3 } & Energy & Utilities \\
\cline { 2 - 3 } $\begin{array}{l}\text { Education/ } \\
\text { Information/ } \\
\text { communication }\end{array}$ & $\begin{array}{l}\text { Schooling and adult } \\
\text { education }\end{array}$ & Utilities \\
\cline { 2 - 3 } & $\begin{array}{l}\text { Phone, computer and } \\
\text { internet connection }\end{array}$ & Telecommunications \\
\cline { 2 - 3 } & $\begin{array}{l}\text { Access to effective and } \\
\text { healthy means of transport }\end{array}$ & $\begin{array}{l}\text { Road, rail etc infrastructure } \\
\text { Public transport services }\end{array}$ \\
\hline \multirow{2}{*}{$\begin{array}{l}\text { Health: prevention, cure, } \\
\text { care }\end{array}$} & $\begin{array}{l}\text { Public health } \\
\text { Medical services } \\
\text { Social care }\end{array}$ & $\begin{array}{l}\text { Public health services } \\
\text { National health services }\end{array}$ \\
\hline Physical security & Emergency services & Emergency services \\
\hline Income security & Employment & Decent, secure job \\
\cline { 2 - 3 } & Income maintenance & Social security; private insurance \\
\cline { 2 - 3 } & Money/payment systems & Retail banking \\
\hline
\end{tabular}

Note:

The middle column denotes contemporary need satisfiers - the potential components of UBS. An attempt has been made in this table to separate out concepts and measures pertaining to individuals and concepts and measures pertaining to collectivities, and to list only the former. Thus desirable collective goals such as gender equality, environmental sustainability and social inclusiveness are not regarded as basic needs, but as general societal preconditions for their satisfaction. ${ }^{6}$

\section{Collective responsibilities and social entitlements}

The essential argument for public provision of some kind is that markets and charity cannot guarantee the meeting of needs. Only public authority can provide equitable entitlements to need satisfiers. Since the Second World War universal needs have provided an essential grounding for appeals to social rights: moral or legal claims possessed by 'right-bearers' that corresponding 'duty-bearers' must take seriously. It is usual here to distinguish 'negative' civil and political rights from 'positive' socio-economic rights. The former entail a duty of forbearance and protection, for example rights to freedom of expression and against discrimination; the latter entail a duty of assistance and provision, for example rights to education or healthcare. Both sets of rights can be traced back to the 1948 Universal Declaration of Human Rights, and have been elaborated and further specified since then.

In the West social rights have provided a fundamental moral argument for welfare states that recognise collective obligations to meet the basic needs of citizens for health, care, education, a minimum income and so on. Though they are subject to constant critiques and counter-movements, there is within them an enduring (if attenuated) sense of social obligation to meet the 'needs of strangers', whose unmet needs we do not directly witness and can do nothing individually to satisfy. At present these obligations end at national 
borders. Large flows of refugees and economic migrants are today questioning who counts as 'strangers' and placing new strains on national welfare systems. A process is underway to reimagine social citizenship, based on plural identities and rights conferred on residents rather than on passport-holders.

Social citizenship is anchored in both ethical and practical considerations. There is a moral dialectic in the ascription of rights and obligations. It is inconsistent to ascribe rights to persons in a social group without also ascribing responsibilities, duties or obligations to group members for realising those rights. And it is inconsistent to ascribe responsibilities to an individual or group without ensuring that they have the wherewithal to discharge them. Feminist revisions of the relationship between needs and obligations have recognised people are vulnerable as well as capable. Dependence on others is a normal part of every life, so for significant periods we must depend on others to provide for us, as we must for them. Caring is the process of 'responding to another's needs by understanding their selfdetermined ends, adopting those ends as one's own, and advancing them in an effort to cultivate, maintain, or restore their agency'. ${ }^{5}$ Obligations thus involve not only avoidance from harm, but also the promotion of capacities for autonomy and self-determination.

The argument thus far is that there exist a number of intrinsic, non-substitutable needs that have a high moral claim to satisfaction and that should be guaranteed to strangers via social rights of citizenship and residence.

The guarantee of entitlements need not entail direct provision of services by state agencies. Indeed from 1980 onwards this system has been broken up in three main ways: non-state providers have been encouraged (both for-profit and not-for-profit), non-state sources of funds expanded, and decisions about what, how much and how to provide have been devolved to intermediate organisations or to end-users. At the same time much of the foundational economy, like energy, water, telecommunications and public transport, has been extensively privatised and outsourced.

Much of this needs to be reversed to achieve UBS, but that does not require a return to a 'pure public' model. Entitlements to UBS can also be guaranteed using a menu of interventions including regulation, standard setting and monitoring, taxation and subsidies. But the unifying proposal is to advocate directly collective solutions, as opposed to providing income support and leaving provisioning to market forces.

To develop this argument the case for collective provision to meet needs can be made on four main grounds: equity, efficiency, solidarity, and sustainability.

Equity and the 'social wage'. The value of free and accessible public services to the individual recipient is frequently called the 'social wage' because it replaces costs that the individual would otherwise have to pay for out of personal income. In the absence of public provision, for individuals on low incomes meeting basic needs is likely to consume the majority of their income. If not, basic needs go unmet with both individual and social costs. If bought on the market these goods and services take up a larger share of household income as we descend the income scale.

This is a major argument for free public provision of necessities financed from taxation. Even if the total tax system of a country is broadly proportional to income, as is the current UK tax system, the overall result will be progressive - the relative size of net income plus services will increase as we descend the income scale. On average, in OECD countries, existing public 
services are worth the equivalent of a huge 76 per cent of the post-tax income of the poorest group compared with just 14 per cent of the richest. Public services reduce income inequality in OECD countries by an average of 20 per cent. ${ }^{9}$ Free provision of necessities automatically targets lower income households, without the disincentive effects that often result from money transfers. Allocation according to need and citizenship, not market demand, automatically serves redistributive social goals.

Efficiency. The argument that markets enhance productive efficiency is well known and valid for many types of goods and services. The dominant argument in economic theory accuses public services of inefficiency, due to lack of competition coupled with the vested interests of bureaucrats and professions. These alleged shortcomings were used to justify introducing market rules into public services from the 1980 s onwards.

Yet the obverse failures of unregulated economic markets to satisfy consumer wants are also well known, including tendencies to monopoly, the inability of markets to supply public goods, the self-defeating production of positional goods, and the inefficiency or diswelfares caused by meeting wants in commodified forms. Transaction costs are often higher for both consumers and providers: the search costs for customers of comparing different pension or utility providers, the administrative costs of drawing up appropriate contracts, the policing and enforcement costs of monitoring large private companies such as Serco and G4S.

Several sectors of the material foundational economy, notably the networked sectors, have large economies of scale, meaning they are 'natural monopolies'. Moral hazards are encountered when profit incentives combine with unequal knowledge in markets. Competition between multiple providers, customer choice for service users and conventional cost-efficiency criteria for measuring success have largely failed to improve social outputs let alone social outcomes.

There are further advantages to a public - rather than market-based - system of service provision. Where efficiency is assessed in narrow output terms, calculations overlook the multiple dimensions of value, the many ways in which value is experienced and how it accrues. The concept of 'social return on investment' (SROI) has been developed over the last decade and adopted by government in the 2012 Social Value Act, which instructs public service commissioners to consider how to 'improve the social, economic and environmental well-being of the relevant area'. Applying social value analysis to an assessment of service efficiency means taking account of longer-term and indirect effects, as well as shorter-term, direct ones. This does not sit easily with a market-based system. If staff delivering meals to people who are housebound take time to sit and chat with them, this may reduce their sense of social isolation and generally improve their wellbeing, but it will increase costs by demanding additional staff time.

Solidarity. The concepts of shared needs and collective responsibilities embody the idea of solidarity, and the practice of UBS has potential to develop and strengthen solidarity. Here we take solidarity to mean feelings of sympathy and responsibility between people that promote mutual support. It is an inclusive process, not just within well-acquainted groups but also, crucially, between people who are 'strangers' to each other. It involves collective action towards shared objectives. ${ }^{10}$ There is a growing literature on the ways in which neoliberal capitalism, based on individualism, choice and competition, weakens the values of social citizenship and undermines solidarity.

UBS calls for collective policy and practice: sharing resources and acting together to deal with risks and problems that people cannot cope with alone. It is not something that can be 
achieved by individuals or groups simply fending for themselves and pursuing their own interests. This is reflected, for example, in the EU's long-standing goal of economic and social 'cohesion': combining a free market economy with 'a commitment to the values of internal solidarity and mutual support which ensures open access for all members of society to services of general benefit and protection.' In the same spirit, the Fabian Society has argued that ending poverty requires a 'solidarity settlement' that would profoundly reshape the welfare system by enshrining 'equal citizenship' and fostering 'a sense of mutual interdependence. ${ }^{11}$

Some have argued that public services 'crowd out' social capital by inhibiting informal caring networks, mutual trust and social norms that favour civil commitment and trustworthiness. However, evidence contradicts this hypothesis, finding instead that Nordic-style welfare regimes, where there are more universal services, tend to have higher levels of bonding and bridging social capital. ${ }^{12}$

Sustainability. One of the particular weaknesses of much public policy is short-termism: taking little account of how major drivers of social, economic and environmental transformation will remould the way the satisfaction of needs is experienced and the resources available to meet them. Yet public services have a greater potential to pursue sustainability goals than programmes to disburse funds for consumer expenditure. In particular they could play a greater role in prevention: 'action to reduce the probability of a risk occurring'. The case for preventive public policy is essentially twofold: it is better for human wellbeing to prevent harm than to deal with its consequences and it promises financial savings to expensive and hard-pressed welfare states. ${ }^{13}$

This is most apparent in facing the most profound, indeed existential, threat to contemporary public policy - climate collapse and extreme environmental stress. The urgent necessity to move away from unsustainable economic, social and environmental practices provides a novel justification for extending universal public services, in three directions ${ }^{14}$. First, public provision of services strengthens the capacity of communities to adapt to or cope with severe climatic and environmental stress. The impact of Hurricane Katrina on the poor and black populations of New Orleans (in contrast to the population of Cuba, affected by the same hurricane) demonstrated the importance of collective services. Second, public services can play a vital role in decarbonising the economy in a just way. For example, Green New Deal programmes to retrofit the vast bulk of the housing stock will require public planning, finance and management. They will be needed to ensure a 'just transition' to lower carbon living, not simply a green capitalist transition that will load costs onto the poorest people and communities.

Third, UBS can play a vital role in switching the entire economy from an obsession with growth to a concern for human wellbeing within planetary limits. Public provisioning systems for healthcare and education are better able than market systems to promote sustainable consumption, to implement national strategies for reducing GHG emissions and to coordinate sustainable practices such as active travel and local food procurement. For example, the mainly privately-funded US healthcare system directly accounts for 8 per cent of emissions in the US, compared with 3 per cent of UK emissions directly stemming from the NHS. This is due both to the greater macro-efficiency and lower expenditure shares of health in the UK, and to lower emissions per pound or dollar spent, presumably as a result of better allocation of resources and procurement practices. There is some cross-national evidence that more extensive and generous welfare states are better suited to adopting and 
implementing pro-environmental policies, especially where they embody ideas about shared needs and collective responsibilities. ${ }^{12}$

\section{Conclusion}

The case for Universal Basic Services made here is one part, but an essential part, of a rejection of turbo consumer capitalism and a renewal of social citizenship: a shift from customers and consumers to residents and citizens. To achieve this will require a resolute confrontation with the ontology and morality of the current economic model. The ontological ground is the existence of core human needs that require collective responsibilities and a renewed foundational economy to fulfill. The normative justification is the superior potential of UBS to secure human flourishing via greater equality, efficiency, collective solidarity and long-term sustainability.

The political argument is that the implementation of Universal Basic Services can achieve results that are superior to a system of unconditional cash payments (a UBI scheme) coupled with markets for commodified services. Of course this leaves open the question, why not advocate both UBI and UBS? There is not the space here to confront that question properly but it embraces consequential and ethical arguments. A universal unconditional living income would require punitive levels of taxation. By focusing wholly on individual income, UBI would threaten public provision of collective consumption, which of course is why many on the libertarian right support it. UBS is fiscally more modest and discriminatory. Common human needs recognise the social foundations of life and the role of contribution to a collective cause: 'from each according to their ability' as a well as 'to each according to their needs'. In this and other ways UBS embodies quite distinct, and I would argue ethically superior, ideas of economy, society, sustainability and social solidarity.

\section{Acknowledgements}

Thanks to Anna Coote for sharing with me ideas and analysis from two forthcoming publications:

A.Coote, P. Kasliwal and A. Percy (2019), UBS Theory and Practice: A Literature Review. Institute for Global Prosperity.

A.Coote and A.Percy (2020), The Case for Universal Basic Services. Polity Press.

\section{Endnotes}

\footnotetext{
${ }^{1}$ Zamora, D. (2017). "The Case Against a Basic Income". Jacobin Magazine.

Martinelli, L. (2017). "The Fiscal and Distributional Implications for different Universal Basic Income Schemes in the UK". Bath: Institute for Policy Research.

${ }^{2}$ IGP (Institute for Global Prosperity) 2017. Social prosperity for the future: A proposal for Universal Basic Services.
} 
${ }^{3}$ Nussbaum, M.C. 2000. Women and Human Development: The Capabilities Approach. Cambridge University Press, Cambridge.

${ }^{4}$ Doyal, L., Gough, I., 1991. A Theory of Human Need. Palgrave Macmillan.

${ }^{5}$ Miller, S.C. 2012. The Ethics of Need: Agency, Dignity and Obligation, Routledge, New York.

${ }^{6}$ Gough, I. 2015. Climate change and sustainable welfare: The centrality of human needs. Cambridge Journal of Economics , 39, 1191-1214.

${ }^{7}$ Fine, B. and Leopold, E. 1993. The World of Consumption. Routledge.

${ }^{8}$ Floud, J., Moran, M., Johal, S., Salento, A., Williams, K. 2018. Foundational Economy: The infrastructure of everyday life. Manchester University Press.

${ }^{9}$ Verbist, G., Förster, M.F. and Vaalavuo, M. 2012. The Impact of Publicly Provided Services on the Distribution of Resources: Review of New Results and Methods. OECD Social, Employment and Migration Working Papers No. 130. OECD Publishing, Paris.

${ }^{10}$ Coote, A. and Angel, J. 2018. Solidarity: Why it matters for a new social settlement. New Economics Foundation.

11 Coote, A. (2017). Building a New Social Commons. London: NEF, https://neweconomics.org/uploads/files/Building-a-New-Social-Commons-WEB-version.pdf Accessed January 2019

${ }^{12}$ Oorschot, WV., and Arts, W. (2005). The social capital of European welfare states: the crowding out hypothesis revisited'. Journal of European Social Policy, 15(1), pp. 5-26.

${ }^{13}$ Gough, I. 2015. The political economy of prevention. British Journal of Political Science, 45(2), 307-327.

${ }^{14}$ Gough, I., 2017. Heat, Greed and Human Need: Climate change, capitalism and sustainable wellbeing. Cheltenham UK: Edward Elgar Ltd. 